\title{
Non-appendicitis Diagnoses in Patients Operated Due to Acute Appendicitis
}

\author{
Akut Apandisit Nedeniyle Ameliyat Edilen Hastalarda Apandisit Dışı Tanılar

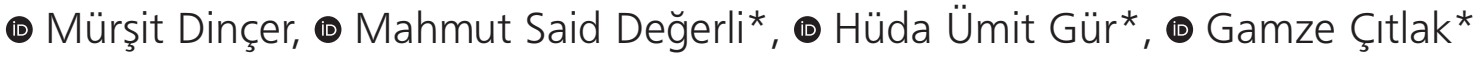 \\ Fırat University Faculty of Medicine, Department of General Surgery, Elazı̆̆, Turkey \\ *Haseki Training and Research Hospital, Clinic of General Surgery, Istanbul, Turkey
}

\section{Abstract}

Aim: The aim of the present study was to evaluate patients who were operated due to acute appendicitis and who were later determined to have non-appendicitis pathologies.

Methods: The demographic characteristics, histopathological results existence of perforation, complications and the length of hospital stay were recorded. The data of the patients who were determined to have histopathological results other than acute appendicitis were analyzed.

Results: A total of 2112 patients, who underwent surgery due to acute appendicitis were included in the study. Sixty-seven-pointfive percent of the patients were male $(n=1426)$. The average age was 33.6 \pm 12.9 years and the median age was 30 (19-90) years. The patients were divided into two groups as those under the age of 30 (Group 1) and above the age of 30 (Group 2). No significant differences were detected between the two groups in terms of histopathological diagnoses, perforation, complication and length of hospital stay. Normal appendix was found in $0.6 \%$ and non-appendicitis pathologies in 1.5\% $(n=33)$ of patients.

Conclusion: Despite advances in radiological imaging a significant number of malignancies and other diagnoses might be detected in patients operated for acute appendicitis; therefore, histopathological analysis of appendicectomy specimens is of great importance.

Keywords: Acute appendicitis, histopathology, surgery
Amaç: Bu çalışmada akut apandisit nedeniyle ameliyat edilen ancak apandisit dışı patoloji saptanan hastaları değerlendirmek amaçlandı.

Yöntemler: Akut apandisit nedeniyle 2009-2014 yılları arasında acil cerrahi girişim uygulanan hastaların dosyaları retrospektif olarak incelendi. Terminal patolojisi akut apandisit dışında saptanan olguların verileri değerlendirildi.

Bulgular: Akut apandisit nedeniyle ameliyat edilen ve kayıtlarına ulaşılabilen 2112 hasta çalışmaya dahil edildi. Hastaların \%67,5'i

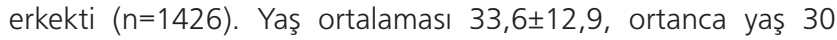
(19-90) saptandı. Hastaların \%1,7'sinde $(n=36)$ apandisit dışı patolojiler (örneğin; nöroendokrin tümör, enflamatuvar bağırsak hastalığı, mukosel vs.) olarak saptandı. On olguda patoloji nöroendokrin tümör, yedi olguda müsinöz neoplazi, üç olguda müsinöz adenokarsinom, üç olguda mukosel ve 10 olguda enflamatuvar bağırsak hastalığı ile uyumlu olarak saptandı.

Sonuç: Radyolojik görüntüleme yöntemlerindeki tüm gelişmelere rağmen akut apandisit nedeniyle opere edilen hastalarda hala azımsanmayacak bir oranda malignite ve diğer tanılar saptanabilmektedir. Bu nedenle ameliyat sonrası histopatolojik sonuçlar yakın takip edilmelidir.

Anahtar Sözcükler: Akut apandisit, histopatoloji, cerrahi

\footnotetext{
Address for Correspondence/Yazışma Adresi: Mürşit Dinçer, Fırat University Faculty of Medicine, Department of General Surgery, Elazığ, Turkey E-mail: drmursitdincer@gmail.com ORCID: orcid.org/0000-0002-1930-0383 Received/Geliş Tarihi: 25 Mar 2019 Accepted/Kabul Tarihi: 29 May 2019

This study was presented in the $10^{\text {th }}$ National Trauma and Emergency Surgery Congress in 2015.

Copyright 2019 by The Medical Bulletin of istanbul Haseki Training and Research Hospital The Medical Bulletin of Haseki published by Galenos Yayınevi. ${ }^{\circledR}$ Telif Hakkı 2019 İstanbul Haseki Eğitim ve Araştırma Hastanesi Haseki Tıp Bülteni, Galenos Yayınevi tarafından yayınlanmıştır.
} 


\section{Introduction}

The most frequent disease of the appendix is acute appendicitis. Acute appendicitis develops in approximately $10 \%$ of the general population in the western countries. The incidence is higher in children and in young adults, and is one of the most common surgical emergencies. The lifetime risk of appendicitis is approximately 7-8\% $(1,2)$. Anamnesis and physical examination are beneficial in making diagnosis. Ultrasonography and computed tomography (CT) are valuable radiological imaging methods for verifying the diagnosis. It is often treated with urgent surgical intervention. In some cases, medical treatment has taken its place in clinical practice (3). However, cases of negative appendectomy are also reported from time to time. For this reason, pathological investigation of the appendectomy specimens is of importance. In the present study, we retrospectively evaluated patients who were operated for acute appendicitis and received diagnoses other than appendicitis.

\section{Methods}

Records of patients who underwent emergency surgery for acute appendicitis between the years 2009 and 2014 in Haseki Training and Research Hospital were analyzed retrospectively. A total of 2112 patients, whose records could be obtained, were included in the present study. The demographic characteristics, histopathological results existence of perforation, complication and length of hospital stay were recorded. Data of patients who were determined to have conditions other than acute appendicitis were analyzed.

\section{Statistical Analysis}

Data were analysed using IBM SPSS version 20.0 (SPSS ${ }^{\circledR}$ Inc., Chicago, IL). Numerical data were presented as mean \pm standard deviation, and the data on demographic features were analysed with the chi-square test and Fisher's exact test. Differences in parameters between the groups were compared using the Student's t-test, MannWhitney $U$ test and chi-square test. A $p$ value of less than 0.05 was considered statistically significant.

\section{Results}

A total of 2112 patients were operated due to acute appendicitis between January 2009 and December 2014. All the patients were diagnosed with acute appendicitis based on physical examination and laboratory and radiological evaluations, and appendectomy was decided. One thousand, four hundred and twenty-six (67.5\%) patients were male and 686 (32.5\%) were female. The median age was 30 (29-87).

The average age was $33.6 \pm 12.9$ years. When the patients were divided into two groups as those under the age of 30 (Group 1) and those above the age of 30 years (Group 2), no significant differences were detected between the two groups in terms of histopathological results presence of perforation, complications and length of hospital stay. When the histopathological results were examined, $0.6 \%$ were found to be normal appendicitis and 1.5\% were nonappendicitis pathologies (e.g. neuroendocrine tumor, inflammatory bowel disease, mucocele, etc.). The pathology was determined as neuroendocrine tumor in 10 patients, mucinous neoplasia in seven, mucinous adenocarcinoma in three, mucocele in three and inflammatory bowel disease in 10 patients (Table 1). All the patients who had malignant tumors were those who were diagnosed with acute appendicitis based on the results of physical examination, laboratory and imaging methods. There were no symptoms suggestive of malignancy. Right hemicolectomy was performed in seven patients of 10 patients who had neuroendocrine tumors. Three patients who had a tumor smaller than $1 \mathrm{~cm}$ in diameter and no poor prognostic features were followed up conservatively. Right hemicolectomy was done in three patients diagnosed with adenocarcinoma according to histopathological analysis. All the patients for whom follow up was decided were assessed every 3 months for the first year after surgery. The physical examination results were evaluated with laboratory and imaging methods. No pathologies were detected in the follow-up period.

\section{Discussion}

Acute appendicitis is the most frequent disease of the appendix. For this reason, appendectomy ranks the first among the most common urgent surgical procedures (4-6). Although appendicitis may be detected at any age, the incidence is higher in young adults. However, in our series, the number of patients who were under 30 years of age and those who were above the age of 30 was nearly equal. The main etiology of appendicitis is obstruction due to fecalit in adults. The most frequent

\begin{tabular}{|l|l|}
\hline Table 1. Histopathological findings in appendectomy specimens \\
\hline Specimens & $\mathbf{n}(\%)$ \\
\hline Appendicitis & $2066(97.8)$ \\
\hline Mucoceles & $3(0.14)$ \\
\hline Musinous neoplasia & $7(0.33)$ \\
\hline Musinous adenocarcinoma & $3(0.14)$ \\
\hline Crohn's disease & $10(0.47)$ \\
\hline Neuroendocrine tumor & $10(0.47)$ \\
\hline Normal appendix & $13(0.6)$ \\
\hline Total & $2112(100)$ \\
\hline
\end{tabular}


reason is hyperplasia of the lymph follicles in the submucosa in children $(7,8)$.

The intra-lumen pressure is increased following obstruction in the lumen, and lymphatic and venous obstruction occurs. If this continues, mucosal edema, ischemia, invasive infection and perforation might follow (8). Anamnesis and physical examination are very important in the diagnosis. Complete blood count, urine analysis, ultrasound and $C T$ are helpful in verifying the diagnosis for surgeons $(9,10)$. Especially ultrasound is advantageous in the diagnosis of acute appendicitis. Compared to ultrasound, CT is more sensitive in the diagnosis of acute appendicitis (5). However, it also has several disadvantages such as not being available in all healthcare centers, exposure to radiation and failure to interpret the results in an accurate manner. In spite of all the developments in imaging methods, the diagnosis of conditions other than appendicitis is still established after appendectomy $(11,12)$. In differential diagnosis, a great number of diseases, such as neuroendocrine tumors, appendix malignancies, mucocele and inflammatory bowel disease, should be considered (7). In the present study, the diagnosis of non-appendicitis was made following histopathological analysis in 33 patients after surgery for acute appendicitis. Neuroendocrine tumors and inflammatory bowel disease were detected in 10 patients. Mucinous neoplasm, mucinous adenocarcinoma and mucocele were among the other non-appendicitis diagnoses. In their systemic review of the literature including all studies on the incidence of histopathologically proven aberrant appendiceal pathology. The detection rate of appendix malignancies was below $3 \%$ in all appendectomies (7). In the present study, this rate was $1.23 \%(n=26)$. The most common primary appendix cancer is neuroendocrine carcinoma $(13,14)$. Mucocele is diagnosed at a rate of nearly $0.3 \%$ in all appendectomy cases (8). In our study, this rate was $0.14 \%$, which is in line with the literature.

In a retrospective analysis of 24,697 appendectomies, Charfi et al. (4) reported that Crohn's disease was determined in the pathological examination in $0.11 \%$ of the cases. This rate was $0.47 \%$ in our study.

Parasites such as Enterobius vermicularis, Balantidium coli and Schistosoma haematobium might cause acute appendicitis symptoms, and parasitic infection findings might be determined in $0.18-4.1 \%$ of cases in pathological analysis $(7,8)$. No parasitic infections were detected in the appendectomy specimens in our study. Tuberculous appendicitis is a rare condition, and the diagnosis is established only based on histopathological examination (8). In the present study, no tuberculous appendicitis was determined in the histopathological evaluation of 2112 cases.
The fact that the present study was conducted in a retrospective fashion in a heterogeneous patient group, and that the diagnosis of appendicitis and appendectomies were carried out by more than one surgeon are the limitations of this study. However, the lack of detection of tuberculosis and parasitic lesions and the Crohn's disease being diagnosed more than the rates reported in the literature are the aspects of the present study that differ from the literature. In this way, we believe that the study will contribute to the literature.

\section{Conclusion}

Acute appendicitis preserves its position as the most frequent condition requiring emergency surgery. However, cases of negative appendectomy have been reported in the literature. Imaging techniques, such as ultrasound and CT are important tools in diagnosing acute appendicitis, and the results must be interpreted more carefully. In addition, histopathological analysis of appendectomy specimens is important considering that patients who receive a diagnosis other than appendicitis might require another treatment.

\section{Authorship Contributions}

Concept: M.D. Design: M.S.D., G.Ç. Data Collection or Processing: M.S.D. Analysis or Interpretation: H.Ü.G., M.D., G.Ç. Literature Search: M.D. Writing: M.D.

Conflict of Interest: The authors declared that there is no conflict of interest regarding the publication of this paper.

Financial Disclosure: The authors declared that this study received no financial support.

\section{References}

1. Stewart B, Khanduri P, McCord C, et al. Global disease burden of conditions requiring emergency surgery. Br J Surg 2014;101:e9-22.

2. Addiss DG, Shaffer N, Fowler BS, Tauxe RV. Tauxe RV. The epidemiology of appendicitis and appendectomy in the United States. Am J Epidemiol 1990;132:910-25.

3. Huston JM, Kao LS, Chang PK, et al. Antibiotics vs. appendectomy for acute uncomplicated appendicitis in adults: Review of the evidence and future directions. Surg Infect 2017;18:527-35.

4. Charfi S, Sellami A, Affes A, Yaïch, Mzali R, Boudawara TS. Histopathological findings in appendectomy specimens: a study of 24,697 cases. Int J Colorectal Dis 2014;29:1009-12.

5. Omiyale AO, Adjepong S. Histopathological correlations of appendectomies: a clinical audit of a single center. Ann Transl Med 2015;3:119.

6. David RF, Thomas DK. Evaluating diagnostic accuracy in appendicitis using administrative data. J Sur Res 2005;123:257-61. 
7. Akbulut S, Tas M, Sogutcu N et al. Unusual histopathological findings in appendectomy specimens: a retrospective analysis and literature review. World J Gastroenterol 2011;17:196170 .

8. Duzgun AP, Moran M, Uzun S, et al. Unusual findings in appendicectomy specimens: Evaluation of 2458 cases and review of the literature. Indian J Surg 2004;66:221-6.

9. Mariadason JG, Wang WN, Wallack MK, et al. Negative appendicectomy rate as a quality metric in the management of appendicitis: impact of computed tomography, Alvarado score and the definition of negative appendicectomy. Ann R Coll Surg Engl 2012;94:395-401.

10. Rao PM, Rhea JT, Rattner DW, et al Introduction of appendiceal CT: impact on negative appendectomy and appendiceal perforation rates. Ann Surg 1999;229:344-9.
11. Andersson RE, Hugander A, Ravn H. Repeated clinical and laboratory examinations in patients with an equivocal of diagnosis appendicitis. World J Surg 2000;24:479-85.

12. Swank HA, Eshuis EJ, Ubbink DT, et al. Is routine histopathological examination of appendectomy specimens useful? A systematic review of the literature. Colorectal Dis 2011;13:1214-21.

13. Shapiro R, Eldar S, Sadot E, et al. The significance of occult carcinoids in the era of laparoscopic appendectomies. Surg Endosc 2010;24:2197-9.

14. Connor SJ, Hanna GB, Frizelle FA. Appendiceal tumors: retrospective clinicopathologic analysis of appendiceal tumors from 7, 970 appendectomies. Dis Colon Rectum 1998;41:7580. 